\title{
Social Investment in an Age of Austerity: A Comparison of Family Policy Reforms in Four European Countries
}

SONJA BLUM*

FernUniversität in Hagen

Hagen, Germany
Original scientific paper

UDK: $364.013-055.5$

doi: $10.3935 /$ rsp.v27i3.1563

Received: June 2018

\section{SÓNIA CORREIA}

Institute of Social Sciences

University of Lisbon

Lisbon, Portugal

\section{MIKAEL NYGÅRD}

Faculty of Education and Welfare Studies

Åbo Akademi University

Vaasa, Finland

\section{TATJANA RAKAR}

Faculty of Social Sciences

University of Ljubljana

Ljubljana, Slovenia

\section{KARIN WALL}

Institute of Social Sciences

University of Lisbon

Lisbon, Portugal

The focus of this article is on family policy reforms in four European countries - Austria, Finland, Portugal, and Slovenia - between 2008 and 2015. These years were marked by the 'Great Recession', and by the rise of the social-investment perspective. Social investment is an umbrella concept, though, and it is also somewhat ambiguous. This article distinguishes between different social-investment variants, which emerge from a focus on its interaction with alternative social-policy perspectives, namely social protection and austerity. We identify different variants along the degree of social-investment: from comprehensive, over crowding out, towards lean forms. While the empirical analysis highlights variation, it also shows how there is a specific crisis context, which may lead to 'crowding out' of other policy approaches and 'leaner'forms of social investment. This has led to strong cutbacks in family cash benefits,

* Sonja Blum, FernUniversität in Hagen, Universitätsstraße 47, 58097 Hagen, Germany, sonja.blum@ fernuni-hagen.de 
while public childcare and parental leaves have proved more resilient in the investigated countries. Those findings are revelatory in the current Covid-19 pandemic, where countries are entering a next, possibly larger economic crisis.

Keywords: family policy, crisis, social investment, austerity, case studies.

\section{INTRODUCTION}

The 1970s and 1980s have often been denoted as the end of the 'golden age' of the welfare state, putting a halt to its expansion in post-war prosperity. Faced with low growth rates and rising unemployment, the recipe chosen by many countries was to 'relieve' labour markets. Alongside such measures as early retirement schemes, family policy was a key part of the reform programme and recourse to parental leave schemes was seen as 'anti unemployment measures' (see e.g. for Germany: Bothfeld, 2005). Following the recent 'Great Recession' (Van Kersbergen et al., 2014), which started in 2008 or thereabouts, something significant changed. Especially at the EU level, one saw the rise of ideas of social investment (Bothfeld and Rouault, 2015). Through this perspective, which was in the making from the late 1990 s, new forms of social policy are ascribed a positive economic role. Investing social policies are thought 'to increase employability and employment levels; to support labour market fluidity [...]; to prepare for the 'knowledge-based' economy' (Morel et al., 2012: 12). Family policy may be said to be at the core of a social-investment strategy, since it centrally involves the wellbeing and functioning of families, and may especially target labour-market participation and gender equality. 'New' social risks, lone parenthood and child poverty, for instance, have been highlighted as requiring a social-investment strategy (Esping-Andersen; Gallie et al., 2002). In times of crisis, family policies should no longer follow the recipe of 'taking pressure from labour markets' (e.g. through extending leave), but rather upgrade active inclusion strategies, e.g. through 'affordable quality childcare and education' (European Commission, 2013a).

We take the rise of the notion of a 'social investment welfare state' (Morel et al., 2012) during the last 'economic crisis' as a starting point to pose two questions. First, as social investment has been described as an ambiguous concept and its relation to classical social-protection policies as underexplored (Nolan, 2013; Bothfeld and Rouault, 2013), we aim at conceptually distinguishing between different social-investment forms through their relation to other social policy perspectives - namely social protection and austerity. Second, we pose the empirical question: what has been the role of those social investment variants in family policy reforms during the economic crisis years?

Previous research has come to differing conclusions about social investment in times of an 'austerity consensus' (Farnsworth and Irving, 2012). Some studies indicate that governments have indeed often safeguarded social-investment policies and additional 'spending for the long run' from cutbacks and have also upheld these investments during the crisis years - particularly in the family policy area of public childcare (see e.g. Adema and Ali, 2015; Windebank, 2017). Others indicate that social investment policies have overseen forms of disinvestment, linked to austerity, which also concern family policies (Ronchi, 2018; Van Kersbergen et al., 2014; Léon and Pavolini, 2014). Relating to childcare, Bothfeld and Rouault (2013: 81) differentiate between different paths: a commitment for expansion, but also a need to reduce expenditure, which 
governments may do by reducing quality standards or withdrawing public subsidies. Research is consistent in finding differing extents and types of social-investment policies among different countries (e.g. Bouget, et al., 2015).

This article contributes to the literature by analysing post-crisis family policy reforms ${ }^{1}$ in four countries with different welfare state backgrounds, namely Austria, Finland, Portugal and Slovenia. Its findings are revelatory in the current Covid-19 pandemic, where countries are entering a next, possibly larger economic crisis, whose effects on family policies remain to be seen. We start by distinguishing between different variants of social investment (Section 2). The third section then accounts for the case selection and methodology of the study. Later sections briefly present the findings of the individual country studies and a comparative conclusion. Based on the findings, the article shows that strong cutbacks in family cash benefits have been more common, whereas public childcare and parental leaves proved more resilient in the four investigated countries.

\section{ANALYTICAL FRAMEWORK: DIFFERENT VARIANTS OF SOCIAL INVESTMENT}

Recent years have seen the rise of the social-investment perspective, even the notion of a 'social investment welfare state' (Morel et al., 2012). Such a popular term, however, risks being used as a buzzword in political discourses without being translated in actual policies. This section sets out to develop concepts to investigate the extent and ways in which social investment is actually implemented in family policy reforms.

Starting with the definition of paradigmatic social investment policies, these are 'capacitating social policies' (Van Kersbergen et al., 2014), such as education and active labour-market policies. In the area of family policy, which is drawn to the core of a social-investment strategy, they are conceived as positive de-familialistic ${ }^{2}$ measures, such as high-quality childcare or leave policies that promote female employment (Morgan, 2012). It has been shown, however, that social investment is an umbrella concept, and also a somewhat ambiguous one (Cantillon and Van Lancker, 2013; Nolan, 2013). Bonoli (2012) described how active-labour-market policies can be a continuation of (neoliberal) workfare policies rather than the social-investment oriented development of 'more and better jobs'. Also, Jenson (2009) pointed out that, while gender and work-family reconciliation are at the centre of the social-investment discourse, core issues of gender equality are typically left out (e.g. men's care work, equal pay) and, as a consequence, the social-investment perspective might even eliminate a gender-equality perspective.

In order to grasp the role of social investment in recent family policy reforms, it is thus helpful to distinguish between different variants. One crucial dimension is how social investment interacts with alternative social policy perspectives. With regard to social policy in general, Morel et al. (2012) have made a well-known distinction between the three perspectives of Keynesianism, Neo-liberalism, and Social investment.

\footnotetext{
${ }^{1}$ By 'post-crisis' we denote policies adopted after the financial and economic crisis set in around 2008, taking into account that the degrees to which reforms were crisis-related differ between policies and countries. We are also aware that the term 'family policy', while having gained prominence, does not exist in all countries as a distinct policy sector. It is therefore further defined in Section 3.

${ }^{2}$ De-familialising policies relax care obligations either through state or market provision (Esping-Andersen, 1999: 6).
} 
Combining this with another categorisation, which focuses specifically on the area of family policy (Blum et al., 2014), we may distinguish three social policy perspectives: a 'social protection/compensation' and an 'austerity' perspective alongside the social investment perspective. ${ }^{3}$

As defined by Van Kersbergen et al. (2014), social protection entails 'measures geared towards the compensation of the income losses of individuals by expanding a programme's generosity or coverage'. Classical social protection policies focus on the male breadwinner and the traditional family (Morel et al., 2012: 6), which also entails benefits to compensate for the existence of children (through child benefits, for instance). Social protection policies often go hand-in-hand with 'familialist' measures (such as cash-for-care benefits or pension credits for childrearing), i.e. measures which shift care responsibility to the family and support parents, in particular mothers, of small children to care for their children at home (Szelewa and Polakowski, 2008; Leitner, 2003; Esping-Andersen, 1999). Indeed, this female care work has been '(p)art and parcel of the Keynesian-Beveridgean welfare compromise' (Hemerijck, 2015).

The perspective of austerity stresses the necessity of making savings and cutting back on existing benefits, e.g. by decreasing benefit generosity, or 'targeting' the measure on certain groups. As Hood et al. (2014) describe it, austerity goes beyond fiscal prudency by invoking neo-liberal ideas. In this vein, welfare state spending and expenditure is primarily seen as a burden, while less state involvement and cost containment are advocated, and ascribed positive effects regarding growth and employment (Blyth, 2013). For family policy, this can translate into clear retrenchment measures (e.g. decreasing child benefits), but also into increasing individual responsibility (e.g. restricting rights to childcare), or privatisation of services (see Nyby et al., 2017).

In the literature, these different social policy perspectives are sometimes described as standing next to each other as separate categories, yet this is not quite the case. First, social-investment policies and social-protection policies can be distinguished as separate perspectives (see also Borosch et al., 2016; Van Kersbergen et al., 2014), yet it is important to highlight that they are not contradictory, but can go hand-in-hand and be mutually reinforcing (European Commission, 2013b). The austerity perspective, on the other hand, is contradictory to social protection or social investment, and may negatively affect respective measures.

Taking this into account, the specific variant of social investment followed in a country does not only result from its social investment policies, but also from the interaction with alternative social policy perspectives and policies. On this basis, we can distinguish between different variants in the degree of social investment (see Figure 1). These differ in whether we find stronger or lower investment in social-investment policies (or even disinvestments), and the extent to which they coexist with investments in or cutbacks of social-protection policies. ${ }^{4}$

To begin with, the 'textbook case' is what Bothfeld and Rouault (2013) call comprehensive social investment. Here, 'adequate minimum income protection is

${ }^{3}$ In line with this research, we suggest that 'austerity' is the currently prevailing concept (see e.g. Blyth, 2013), which we will use instead of neo-liberalism. Like social investment, austerity has also been described as an ambiguous term, though. Furthermore, when focused on policy outputs, 'Keynesianism' entails ('passive') risk protection, social insurances and policies to sustain demand (see e.g. Morel et al., 2012).

${ }_{4}$ Strong expansions of social protection policies are not to be expected based on the theoretical and empirical literature, but in our typology these would be equivalent to small adaptations. 
a critical precondition for an effective social investment strategy' (Hemerijck, 2015: 248; see also Morel et al., 2012). In that sense, comprehensive social investment goes hand-in-hand with social protection, particularly for vulnerable groups. Correspondingly, we would find strong social investment policies and investments or at least no major cutbacks of social-protection policies under such an approach. talk of crowding-out social investment, where social-investment policies are expanded, but 'at the cost' of social-protection measures, where we find significant retrenchment.

Furthermore, a 'social-investment strategy' may be spoken of while actual investments remain low. If such low investments in social-investment policies are accompanied also by - stronger or weaker - cutbacks

Figure 1

Strength of social-investment focus

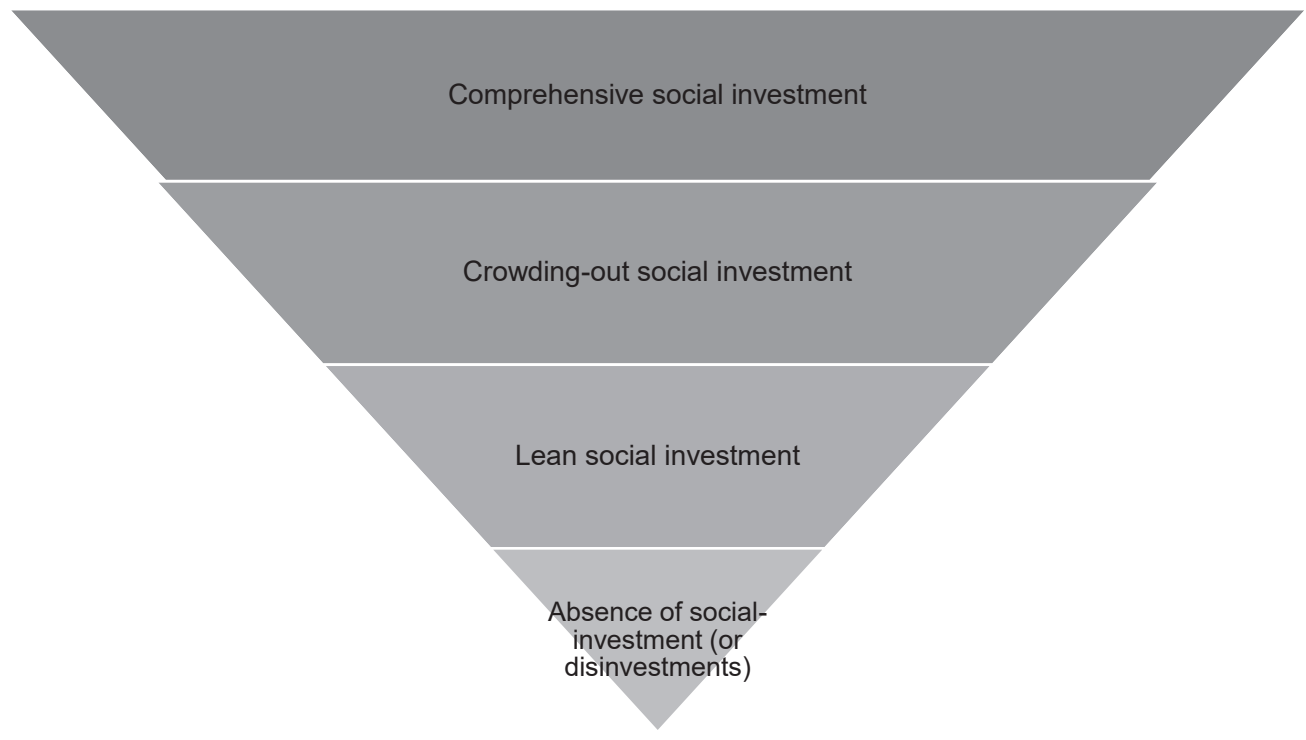

Source: Own figure.

In practice, however, social investment is not necessarily contradictory to welfare state retrenchment, as it can go hand in hand with a shift-away from 'passive' social protection and produce 'Matthew effects', whereby middle- and higher-income groups are privileged (Cantillon, 2011; Bonoli et al., 2017) $)^{5}$. In that case, we may of social-protection policies, we may speak of a lean social investment type (Van Kersbergen et al., 2014). This is also reminiscent of what Hemerijck (2017; see Bonoli, 2013) labels as 'affordable social investment'. Last but not least, we may of course also find the absence of a social-investment focus (or disinvestments of a previous such focus),

${ }^{5}$ Cantillon (2011) identified declining generosity of traditional income support and argued that social investment 'may at least in part be responsible for disappointing poverty trends'. 
again going more or less hand-in-hand with social-protection reforms.

\section{METHODOLOGY}

To effect a comparative analysis of four countries, we will narrow the focus here to three core family-policy areas (Gauthier, 2010, p. 3): child/family cash benefits and tax reliefs; parental leave; and childcare. How would these policies look like under the different social-investment variants distinguished above? Childcare and leaves are more vital within a social-investment approach, while cash transfers are more typically associated with classical social-protection policies (see Borosch et al., 2016; Bouget et al., 2015; Van Kersbergen et al., 2014). Part of the cash benefits can be what Hemerijck (2015: 248) associates with a 'buffer' function or 'Keynesianism through the back door' within a social-investment approach. While leave policies are often labelled as social investment per se, we argue that only 'gender-equal leaves' (Dobrotić and Blum, 2019; Dearing, 2016), aimed at work-family reconciliation and re-commodification of women, are in line with a social-investment approach. Familialist leaves, on the other hand, are a classical social-protection measure and actually a cornerstone of the Keynesian approach. Thus, we operationalise childcare and gender-equal leave reforms as social-investment policies, while cash/tax benefit and familialist leave reforms are operationalised as social-protection policies. While this distinction is somewhat simplifying and in reality not clear-cut, ${ }^{6}$ it has already been successfully employed for analytical purposes by other studies (e.g. van Kersbergen et al., 2014). Measures against 'child poverty' may illustrate this analytical distinction: from a social-protection perspective, a prime measure against this problem would be cash benefits (such as child benefits), whereas a social-investment perspective prioritizes employability of (single) parents and education. From the austerity perspective, we would primarily expect cutbacks of social-protection policy, but a general austerity climate may support disinvestments of social-investment policies, too.

Austria, Finland, Portugal and Slovenia can be seen as different welfare state types historically. ${ }^{7}$ While all four countries adopted a certain social-investment focus (see Bouget et al., 2015), their different traditions relate to a different currency of social-investment ideas. Namely, in specific typologies of family policy and familialism, the four countries show an interesting variation. Austria has a strong familialist tradition (Leitner, 2003) and has only recently adopted a social-investment focus, whereas Finland as a Nordic country shows more de-familialistic traditions, but also some mixed idiosyncracies (ibid.). Amongst the post-socialist countries, Slovenia has been connected with supported de-familialism (Javornik, 2014), and comparatively strong social-investment traditions (e.g. through public childcare). Portugal as a Southern-European type shares the rather residual welfare state tradition (e.g. in childcare), but in the early 2000s a 'decisive Scandinavian turn' (Ciccia and Verloo, 2012: 522) was diagnosed in its parental leave polices,

\footnotetext{
${ }^{6}$ This is also highlighted by the European Commission (2013b) which states three welfare state functions (social investment, social protection, stabilisation of the economy) and that social 'policies often have two or even all three of the functions', so that it would be 'misleading to allocate individual parts of a budget to a specific function'. Against this backdrop, such functions can only be identified through in-depth qualitative assessment of the measures.

${ }^{7}$ Esping-Andersen's (1990) typology designates Austria as conservative, and Finland as a hybrid version of the social-democratic model. Portugal has been characterised as Southern-European (Ferrara, 1996) and Slovenia as a post-socialist welfare state (Cerami and Vanhuysse, 2009).
} 
with a focus on gender-equal work share and social-investment ideas. Bothfeld and Rouault (2013: 60) argued that EU countries will adopt different social-investment strategies 'according to their basic welfare-type pattern'. Against that backdrop, a comparison between the four countries is particularly interesting. Especially in the countries with a weaker social-investment tradition, it is plausible that an external shock, such as the crisis, brought a new logic to policymaking, emphasising a need for retrenchment and therefore putting a halt to cost-intensive social-intensive measures. For example, Kersbergen et al. (2014: 895) concluded from their study of post-crisis reforms that family and work-life reconciliation policies in Denmark and Germany 'seem to be considered luxuries which governments can no longer afford'. addressed as an outlook in the concluding section. While the extent to which the countries were affected by the 'Great Recession' differed (see Figure 2), the timing at which they were hit and developed back into GDP growth was similar. The chosen period of investigation thus enables us to study the social-investment pathways in family policies comparatively; which were possibly also affected by the severity of crisis (with Portugal and Slovenia being particularly hard hit; see Figure 2). The empirical evidence for the study is based on an analysis of policy change in each country and semi-structured interviews with policy experts. The interviews were conducted in late 2014 and early 2015 in Austria (8 interviews, including a focus group), Finland (5), Portugal (8), and Slovenia (7). The interviewed experts mainly included policy-

Figure 2

Real GDP growth (percentage change on previous year)

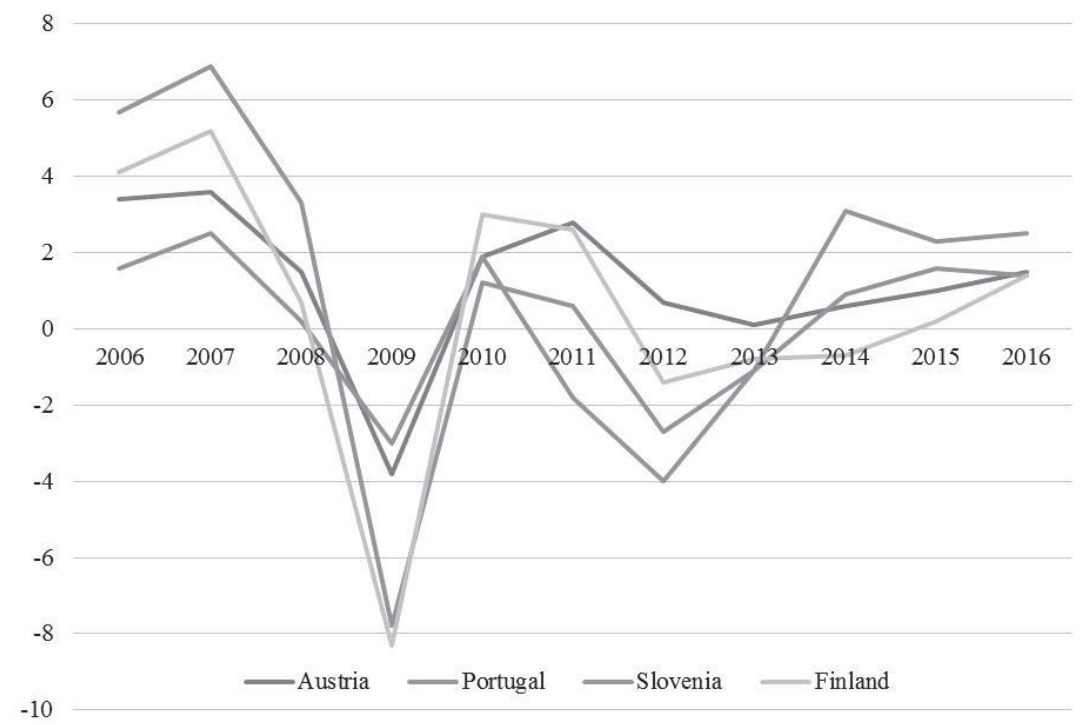

Source: Eurostat.

As regards the period of investigation, our analysis covers the (post-)crisis years from 2008 to 2015; later developments are makers and ministry officials, but also the representatives of interest groups, NGOs, social workers and researchers. The par- 
ticipants in the focus groups were benefit recipients and claimants. The evidence is backed up by an analysis of key documents, such as legal texts, parliamentary protocols, or newspaper articles.

\section{FAMILY POLICY REFORMS AND SOCIAL-INVESTMENT VARIANTS IN FOUR COUNTRIES}

Existing research on crisis-related family policies which reviewed the situation in the EU to 2010 (Gauthier, 2010; Richardson, 2010), showed that both retrenchment and expansionary measures were involved. The expansion was often part of economic-stimulus measures, such as investments into childcare facilities. Austerity measures, dominating in 2010, included postponements of planned expansions, cuts in family benefits, and reductions in parental leave. Expansionary measures were more frequently reported in the area of work-life balance, and cutbacks more in cash benefits (Gauthier, 2010). We now present our research which covers the policy developments in the four countries from 2008 to 2015 (for a comparative overview see Table 1 in the Annex).

\section{Austria}

While Austria went through the fiscal and economic crisis comparatively unscathed, there have been different stages of policy responses during the time when successive grand coalitions of Social Democrats and Conservatives were in government since 2007. In the first stage of economic-stimulus measures, expansionary reforms were introduced in the fields of family cash/ tax benefits and childcare services. In 2009, childcare costs were made tax deductible, up to $€ 2,300$ per year and child. Also, the general tax credits for children were raised. Both measures were part of a larger tax reform, which had been planned earlier, but was brought forward with the economic crisis identified as an argument for this earlier implementation (Blum et al., 2014).

Regarding parental leave, an additional income-dependent variant was introduced from 2010. This increased the number of available variants to five. The new variant replaces $80 \%$ of the former net income for 12 months, plus an additional 2 months if these extra months are taken by the other parent. It therefore aimed at a quicker return to paid employment as compared with the other, longer variants that continue to exist; those targeted include higher-educated mothers and fathers as leave takers. Gender-equal leave was thus expanded. An expansionary focus was also visible in public childcare. A compulsory last pre-school year that is free of charge for the parents was introduced in 2009. As an investment in infrastructure and corresponding jobs in this sector, the measure was part of an economic-stimulus package. It showed a social-investment focus and was directed at enhancing language skills of children, particularly in the context of integration policy (Der Standard, 2008).

In the second stage of crisis-oriented measures, overall family policy expenditure in Austria shrank in 2011 - for the first time after a long phase of continuous expansion. The age limit to receive family allowance for 'children' in education was reduced from 26 to 24 years. Family allowance was completely abolished for job-seeking "children' aged 18 to 21 years. The sole-earner tax deduction was abolished for couples not receiving family allowance. Overall, this austerity focus of 2010/11 remained limited when compared to many other EU countries, and targeted family cash and tax benefits.

Childcare for under-threes has been significantly expanded since 2008. Repeated investment packages were agreed upon by the national government and the federal 
states (the latter being responsible for childcare in Austria). As a result, participation rates for under-threes in formal childcare rose from $11.8 \%$ in 2008 to $25.5 \%$ in 2015 (Statistik Austria, 2008, 2015).

Childcare remained an important issue on the political agenda. The next set of reforms was initiated by the grand coalition of Social Democrats and Conservatives (201317) after the national elections of September 2013. 2014 saw the most comprehensive agreement on childcare expansion, whereby the central state invested $€ 305$ million and the federal states $€ 135$ million until 2017. Once again the places for under-threes were prioritised, but funds were also invested in the training of child-minders and the expansion of all-day schooling. Furthermore, another - larger - reform of the family allowance was set in train: the universal benefit was raised by $4 \%$, with subsequent raises by $1.9 \%$ both in 2016 and 2018 .

Overall, with the notable exception of the 2011 austerity measures, the 2008-2015 pathway of Austrian family policy was one of expansion. This can be traced back to the comparatively low crisis effects, as well as the prevalence of social-investment ideas. As one interviewed expert put it:

Looking back at the last years, there have been quite a few improvements in family policy, namely regarding the childcare infrastructure. It came as a bit of a surprise, there have never been such high funds before. But it has also been inserted into the crisis reaction to say: Investments, we need investments! And it has worked out that childcare was seen as an element in this. (Interview AT-1)

Part of this is a new understanding of social services not as a burden, but as a motor for employment - where "particularly in times of high unemployment it is clever to invest here' (Interview AT-1). This includes both the direct creation of jobs (e.g. for pedagogues, building industry) and the support of (women's) employment by providing public childcare. Overall, Austrian family policy has been dominated by the focus on work-life balance - in the Social democratic party, but increasingly also amongst the Conservatives (Focus group AT-1). This is seen as part of family policy modernisation (Focus group AT-1; Interview AT-1), which is most evident in the parental leave benefit reforms: there, the social-investment perspective partly sidelined the strong familialist social-protection tradition (Leitner, 2003).

\section{Finland}

In Finland, the most immediate family policy response to the international financial crisis was expansive, with piecemeal improvements of some family cash transfers (e.g. child benefits). Since the crisis was viewed as temporary, the centre-right government in office at the time (2007-10) sought to shelter families from the economic downturn in line with a social-protection perspective, rather than resorting to austerity measures (Nygård and Autto 2014; Interviews FI-1-3). Simultaneously, however, steps were also taken to enhance the social-investment perspective in Finnish family policy. The centre-right coalitions in office 2007-10 and 2010-11 acted as vanguards for these social-investment reforms, but some of them were not implemented until the reign of the subsequent right-left ('six-pack') coalition (2011-14). The perhaps most important reforms were the gradual extension of the fathers' leave (in 2010 and 2013) and the introduction of a flexible care allowance (in 2014). Together these sought to increase the level of parental (notably maternal) employment, strengthen gender equality and enhance work-family balance (Finnish Parliament, 2013; Interviews FI-1-4).

However, considering the fact that social-investment policies, such as public 
childcare, have a long tradition in Finland, these investments perhaps represent little 'new under the sun'. Rather, they can be seen as steps of a national adaptation to EU policy recommendations (e.g. the Europe 2020 strategy) striving e.g. at higher parental employment as a way of strengthening the fiscal sustainability of the welfare state (Nygård and Autto 2014; Interview FI-5).

The combination of (modest) cash-benefit improvements and investments in parental leave (and work-family balance) during the period 2009-14 thus suggests a policy development in accordance with a comprehensive social-investment variant. However, since 2012 this pathway became gradually intertwined with an austerity perspective, advocating stricter fiscal control and cutbacks in family cash benefits and services. In the face of continuing economic recession in Finland, the right-left coalition gradually abandoned a social-protection perspective and focussed more squarely on cutting expenditures and balancing the public economy while simultaneously committing to the imperative of getting more parents into the labour market (Nyby et al., 2018; Nygård and Autto, 2014).

The main objective here was to get more mothers into the labour market, even as part-time employed. [...] This is just an example of how the economic situation and the employment imperative are used to justify reforms. (Interview FI-4)

In 2012, the government temporarily abolished the yearly inflation adjustments of the child benefit for a three-year period. A direct cutback of the child benefit followed in 2014 (by 8\%). To compensate low-income families, a child-tax deduction was introduced, but this was criticised for being inefficient since low-income families pay low taxes and are therefore unlikely to benefit from such a deduction (Interview FI-4). However, the perhaps most conspicuous cutback was the curtailment of the right to full- time childcare in 2015. This reform, which was preceded by another reform aimed at strengthening the educational quality of the childcare system (also in 2015), abolished the longstanding universal right for all children to receive full-time childcare, by making this conditional of parental employment. Also the 'familialist' child home-care allowance (and leave) system, enabling home-care of children under three, became subject to increasing criticism for being counter-productive to parental employment and gender equality (Ministry of Social Affairs and Health, 2011). However, it has so far remained unchanged, which suggests that familialist values still hold sway alongside social-investment ideas of gender equality.

Taken together, the Finnish family policy development 2012-15 can be said to have shifted from a comprehensive towards a lean social-investment variant. Several cutbacks have been made in both family cash benefits and the universal right to public childcare has been restricted, while expansive social investments have been scarce after 2014. True, in a way the restriction of the right to childcare can be considered as a way of forcing parents into the labour market, but it seems questionable if we actually can regard this as a 'school-book' social-investment manoeuvre. Instead, the policy development seems to have become increasingly conditioned by a need to contain public expenditure, to cut government debt and achieve fiscal prudence in accordance with ideas from an austerity perspective (cf. Blyth, 2013).

In sum, the Finnish case shows that although the early responses to the great recession were expansive in terms of cash benefit improvements and a number of important reforms advocating parental employment and gender equality were made, since 2012 there has been a gradual shift towards at best a lean social-investment 
variant, which has brought with it cutbacks in child benefits as well as public childcare. This shift and the cutbacks have been justified mainly by economic reasons - as inevitable actions needed to raise employment and to cut expenditures in order to maintain the fiscal sustainability of the Finnish welfare state.

\section{Portugal}

Coming from a tradition underscoring a rudimentary, familialistic welfare state, Portuguese family policies after the transition to democracy (1974) introduced an explicit focus on state responsibilities to support a dual-earner, gender-equality-oriented model. This led to a gradual but steady increase in entitlements to family benefits, leave schemes and public childcare services (Wall, 2011). During the early 2000s, this social-investment perspective was further expanded, both in the context of a centreright-wing coalition government and of two governments led by the socialist party. Family benefits were increased; family diversity was underlined through support for lone parents and immigrant families; parental leave was made more generous and fathers' involvement in childcare was promoted (e.g. compulsory two weeks fully-paid paternity leave in 2004; sharing bonus in 2009). Lastly, investment in childcare services had led, before the onset of austerity in 2010, to coverage rates above the Barcelona target of $33 \%$ for under-threes. Family policies during this expansionary phase had also shifted toward a specific welfare mix in which different actors - state, families, private profit and publicly-subsidised non-profit institutions - took on responsibility jointly (Wall et al., 2013).

Policy responses after 2010 followed two main steps. Between 2010 and mid2011 (Socialist Party in government), reforms focused on reducing benefit generosity and strongly affected the main family benefit (two out of the five income levels were abolished, thereby increasing selectivity). Retrenchment was seen as a temporary cutback in benefits rather than a change in the long-term policy framework and a global-investment perspective in families.

Between 2011 and 2014, following the intervention of the TROIKA (put in place as part of the country's financial bailout) and the election of a right-wing coalition government, reforms involved retrenchment and a shift in policy discourse. Family policy moved into the shadow of social-policy ideas underlining weak governmental responsibilities, third-sector assistance and re-familialisation. To support needy persons in times of crisis, the government introduced one main policy instrument, the Social Emergency Programme. It aimed to reach out to individuals in extreme poverty by providing support on an in-kind basis, through a network of third-sector canteens. Selectivity was increased and benefit amounts cut back further, while existing programmes to support childcare expansion were suspended. The retrenchment introduced in response to the crisis has thus affected all family policy areas, but was strongest in cash benefits (OECD, 2014). Those were changed along two main lines: increased selectivity, with eligibility criteria focusing on support for families with very low income, and cutbacks in benefit amounts. The drop in the number of beneficiaries was sharp between 2010 and 2011, and there has been a continuing decrease between 2011 and 2015. Additionally, there were cutbacks in the support for 'very poor' families on minimum-income benefits (e.g. sharp decrease in benefit amounts per child).

The interviews with policy experts and representatives of local NGOs and authorities highlighted the consequences of these developments. Policy experts reflected mainly on the implications of austerity for 
low-income families, those which, according to them, should receive more support in times of crisis. Commenting on the average poverty rate, which rose to $22 \%$ in 2012 for families with children (compared to $15 \%$ for families without children), one expert considered that 'a basic measure to fight poverty intensity and to reach out to the poorest of the poor, has been almost neutralised'. NGO representatives underlined that retrenchment had weakened support for families living in 'endemic poverty'. They also highlighted 'new contexts of poverty', such as average-income families hit by unemployment and salary cuts.

Policies concerning leave entitlements and services underwent less change. The promotion of work-family balance for dual-earner families with children has remained on the policy agenda, even if measures also underline retrenchment. For example, in the absence of programmes to expand the number of crèches, the main measure adopted was a legal change allowing for more children per classroom. There were also cutbacks in other fields of work-family balance, such as extra-school activities - thereby shifting more responsibility on to families.

The economic crisis therefore led to major changes in Portuguese family policy. Policies moved away from a social-investment pathway and state responsibilities, towards an implicit and residual perspective. Nevertheless, faced with rising poverty levels and negative trends regarding family wellbeing (e.g. fertility dropped to 1.21 in 2013), governmental policies from 2014 onwards re-introduced a focus on the need to invest in families and children. Rather than a comprehensive social-investment perspective for families though, one main objective was underlined: promoting fertility. The 2014 tax reform introduced changes in income-splitting arrangements to explicitly promote large families. Other measures included increasing compulsory paternity leave by one week. There was thus a gradual return to a lean social-investment variant, but in a new context where it was mixed with paradigms of familialism (and pro-natalism) as well as austerity (e.g. subjection of family policy to 'poor relief' perspectives).

\section{Slovenia}

In Slovenia, the major driver behind the recent welfare reforms was the challenge of ensuring sustainability of the welfare system and responding to the economic crisis (Filipovič Hrast and Kopač Mrak, 2016). New social legislation came into force in 2012 and brought significant changes in the field of social and family benefits. According to the interviewed policy experts and government documents, the aim was to form a more just, effective and long-term sustainable welfare state. The law introduced a common entry point for all family and social benefits and defined uniform eligibility criteria for different benefits and for assessing income and property of households. Furthermore, as a direct response to the crisis, two intervention acts were adopted that introduced temporary austerity measures with an indefinite time limit: they are to remain in force until one year after national economic growth exceeds $2.5 \%$ of GDP. These reforms made family benefits more means-tested, and lowered the level of some benefits, including leave policies. This was the first time after the Slovene independence that family policy was affected by austerity measures, despite the fact that the mid-1990s were years of economic crisis.

In 2014, a new 'Parental Protection and Family Benefits Act' was passed, which brought changes in leave policies and child benefits for single parents. In line with the social-investment perspective of promoting work-life balance and mothers' employment, it introduced more gender-equal 
leave policies and changed parental leave from a family entitlement to an individual entitlement. Most of these measures came into force in 2014, but the expansionary measures (e.g. gradual prolongation of paid paternity leave) have a delayed implementation dependent upon GDP growth exceeding $2.5 \%$. Furthermore, the child benefit for lone parents was increased, thus focusing on the most disadvantaged families. However, it reaches only a small part of lone-parent families, due to the narrow definition of this group and an implementation gap.

The evidence suggests that the post-crisis family policy reforms in Slovenia have been predominately characterised by retrenchment and austerity. With the introduction of strict means-testing, a shift towards selectivity in family policy can be identified, targeting not at families in general, but the most disadvantaged groups. This shift is best shown in the paradigmatic change in the purpose of the child benefit. The function was no longer to cover for extra expenses associated with children but rather to provide a survival income for poor families. The child benefit is no longer something that represents an 'added value', but rather a 'social corrective' intended for the survival of the family (Interview SI-4).

Regarding childcare subsidies, austerity measures were introduced in the form of a new calculation of family income. Furthermore, the second child co-currently enrolled in preschool no longer attends free of charge. Leave policies were also affected, since the wage compensation for parental and paternity leave was lowered, and an upper ceiling for the maternity leave benefit was introduced. However, the most fundamental changes and austerity measures were in the area of family cash benefits, which, as mentioned above, were framed as social transfers for the most needy, in line with increased selectivity. Nevertheless, there is evidence of some social-investment orientation, e.g. childcare services saw no cutbacks.

The changes in the examined period can be interpreted as a shift from the pre-crisis pathway, which was characterised by extending social-investment policies, stemming from the socialist past and communist ideology about gender equality (Kanjuo Mrčela and Černigoj Sadar, 2011), to a pathway marked by austerity and retrenchment - predominantly in the area of social-protection policies. It is telling that the government decided to prolong most austerity measures and only partly introduce expansionary ones, even when Slovenia's GDP reached the required growth rate in 2014 (2.6\%). As stressed by a policymaker:

Regarding the austerity measures, every policy should make some sacrifices to show cooperation. And we put our efforts in the compromises to choose the cuts by which families will be least affected, since the families are the ones indirectly affected by all the intervention measures and suffer the most. (Interview SI-3)

\section{CONCLUSIONS: FAMILY POLICY REFORMS AND SOCIAL-INVESTMENT VARIANTS}

The case studies show that there have been different stages to post-crisis family policy reforms and that there is a considerable cross-national variation. Austria and Finland show the first stage of economic stimulus measures around 2009/10 (e.g. childcare expansion in Austria). In the second stage, all of the five countries implemented crisis-related austerity measures around 2010/11. In Austria and Finland these austerity packages remained limited, while in the other two countries they were more extensive. After 2012, Austria and Finland parted company: Austria implemented largely expansionary family 
policy reforms, while in Finland the initial expansions were increasingly accompanied by cutbacks, e.g. in the main child benefit. Portugal and Slovenia did not exit the stage of strong cutbacks in family policy until 2015. In these two countries, an austerity-oriented programme continued to drive developments (although each also shows some limited social investment).

In order to conceptually grasp the varying character of social investment and its relation to other social-policy perspectives, we distinguished four possible directions: comprehensive, crowding-out, or lean social investment, as well as the absence of a social-investment focus (Section 2). The empirical analysis reveals that the four countries show very different variants of social investment. These are not necessarily stable within one country over the whole period (2008-2015).

On the one hand, the social-investment approach seems to be of importance in all the countries. Ideas around social-investing family policies seem to have often safeguarded the areas of parental leave and childcare from (direct) cutbacks. This corresponds to the results of Adema and Ali (2015: 145), who found that 'leave arrangements and childcare support systems have remained largely unscathed in most OECD countries', while many countries implemented cutbacks in financial family support in view of budgetary pressures (see also Bouget et al., 2015: 23). Crowding-out social investment therefore seems quite common. As regards social policy in general, Borosch et al. (2016) also report that universal risk-prevention programmes suffered cutbacks in many European welfare states.

And yet, both the strength of social-investment policies as well as the relation to more classical social-protection policies differ. In Austria, the social-investment perspective that leads the welfare state to invest in children, mothers' employment and new jobs in the social sector gained significant traction. Traditional familialist ideas were side-lined in the process, but by no means replaced, as there remains a strong emphasis on family care predominantly provided by women (Österle and Heitzmann, 2020: 33). At the same time, austerity ideas remained marginal in Austria, also in social-protection measures, wherefore the dominating pathway is one of comprehensive social investment. In the beginning of the investigated period, this was similar in Finland, but from 2012 onwards family policy there has become increasingly viewed as an economic burden. Such economic-burden arguments are contradictory to social-investment arguments. In the consequence, the Finnish case study shows cutbacks not only in the social-protection area (child benefit), but partly also in social-investment policies (decreased right of children to public childcare in the case of non-working parents) - thus forming at best a lean social-investment variant.

In Portugal and Slovenia, the dominant perspective of family policy reform in the years 2008 to 2015 was that associated with austerity. In both countries, the central reform thrust was to focus family policy on those 'most in need'. This corresponds to findings for overarching social policy trends in Europe, which emphasise retrenchment, activation, early intervention, and also an increased selectivity (Borosch et al., 2016). In a number of European countries, a milieu of permanent austerity seems characteristic of the current period. The case studies show how this can sometimes replace social-investment ideas, but sometimes also co-exist with them and give social investment a particular spin. As a case in point, Slovenia was on a pathway of austerity, due to strong cutbacks in social-protection policies in line with increased selectivity, and at the same time 'sheltering' social-investment policies (such as childcare, leave policies), which also witnessed some expansionary 
measures in terms of introducing more gender-equal policies. ${ }^{8}$ Portugal, however, not only poses an example of the social-investment perspective being sidelined by the austerity paradigm, but also of its re-emergence in a changed context. Since the end of 2015, also following a change of government, social-investment ideas have re-emerged in Portugal. But while the focus is shifting again toward social-investment perspectives and increased state responsibilities, the previously established 'poor-relief' perspective of austerity also continues to prevail.

Extending the view to more recent developments reveals both continuity and change. In Austria, yet another reform of the childcare benefit was introduced, effective from March 2017, which is in line with social investment. The four flat-rate variants were transformed into a flexible 'time account', and a gender-equality bonus is now paid if parents share the leave equally. In Portugal, in 2016 the focus turned to the gradual removal of cutbacks, new measures to increase cash benefits for families with children below age three, and state support to promote work-family balance through service expansion. In Slovenia, in 2018 some of the austerity measures were abolished (in child benefit and childbirth grant), and paid paternity leave was prolonged. This trend continued in 2019 (concerning parental leave, child benefit, and large family allowance). Yet the newer developments do not suffice to say that a social-investment focus would have re-emerged over the austerity course, since the selectivity of social protection legislation became permanent (Filipovič Hrast and Rakar, 2020: 497). In Finland, the drive towards austerity has even increased, e.g. resulting in 2016 in a complete abolishment of the yearly indexation of child benefits (see also Nyby et al., 2017).
To conclude, the case studies have shown how social investment has remained important for the family policy packages in all the four countries, also during the crisis, but social-investment variants differ considerably - ranging from comprehensive social investment (Austria) to its crowding-out in face of austerity (Slovenia); while Finland and Portugal showed a lean social-investment approach. This shows how social-investment variants vary in their implementation, depending on the timing and how they are combined with other perspectives, particularly austerity and social protection. Longer-term family policy directions following the Covid-19 crisis need to be awaited, but our findings could be revelatory in this regard and, in the future it will probably be important to compare both periods. Our results underline the points made by Bonoli et al. (2017) about the ambiguity of the social-investment perspective, and how it may be understood as building up on traditional social protection, or as (partly) replacing it. Our results contradict a tendency in the literature to describe the social-investment, social-protection and austerity perspectives as separate and distinct (e.g. Blum et al., 2014). We suggest that while it is helpful to conceptually distinguish between the perspectives, it is even more helpful to further develop conceptually how they are combined, what the resulting logics are in terms of actual policy reforms, and, in future research, how the co-existence of different configurations can be explained.

\section{Acknowledgement}

This paper originates from a Eurofound project, coordinated at the Austrian Institute for Family Studies at the University of Vienna (contract 14-3030-65). We would like to thank the two anonymous reviewers, Daph-

\footnotetext{
${ }^{8}$ As discussed earlier (Jenson, 2009), gender equality can be a central element within the social-investment paradigm (e.g. in Finland), but can also be sidelined by it.
} 
ne Ahrendt, Mary Daly, Tomasz Inglot, Kimberly Morgan, and Holger Straßheim for their valuable feedback on earlier versions of this manuscript.

\section{REFERENCES}

Adema, W., \& Ali, N. (2015). Recent changes in family outcomes and policies in OECD countries: the impact of the economic crisis. Community, Work and Family, 18(2), 145-166. https://doi.org/10.10 80/13668803.2015.1013020

Bonoli, G. (2012). Active labour market policy and social investment: A changing relationship. In N. Morel, B. Palier \& J. Palme (Eds.), Towards a Social Investment Welfare State? Ideas, Policies and Challenges (pp. 181-204). Bristol: The Policy Press.

Bonoli, G. (2013). The origins of active social policy: Labour market and childcare policies in a comparative perspective. Oxford: Oxford University Press.

Bonoli, G., Cantillon, B., \& Van Lancker, W. (2017). Social investment and the Matthew Effect. Limits to a strategy. In A. Hemerijck (Ed.), The Uses of Social Investment (pp. 66-76). Oxford: Oxford University Press.

Borosch, N., Kuhlmann, J., \& Blum, S. (2016). Opening up opportunities and risks? In K. Schubert, P. de Villota \& J. Kuhlmann (Eds.), Current Challenges to European Welfare Systems (pp. 769-791). New York: Springer.

Bothfeld, S. (2005). Vom Erziehungsurlaub zur Elternzeit: Politisches Lernen im Reformprozess. Frankfurt: Campus.

Bothfeld, S., \& Rouault, S. (2015). Families Facing the Crisis: Is Social Investment a Sustainable Social Policy Strategy?. Social Politics, 22(1), 60-85. https://doi.org/10.1093/sp/jxu014

Bouget, D., Frazer, H., Marlier, E., Sabato, S., \& Vanhercke, B. (2015). Social investment in Europe. A study of national policies. Luxembourg: Publications Office of the European Union.

Blum, S., Formánková, L., \& Dobrotic, I. (2014). Family policies in 'hybrid' welfare states after the crisis: Pathways between policy expansion and retrenchment. Social Policy \& Administration, 48(4), 468-491. https://doi.org/10.1111/spol.12071

Blyth, M. (2013). Austerity. The history of a dangerous idea. Oxford: Oxford University Press.

Cantillon, B. (2011). The paradox of the social investment state: Growth, employment and poverty in the Lisbon era. Journal of Europe- an Social Policy, 21(5), 432-449. https://doi. org/10.1177/0958928711418856

Cantillon, B., \& Van Lancker, W. (2013). Three shortcomings of the social investment perspective. Social Policy and Society, 12(4), 553-564. https:// doi.org/10.1017/S1474746413000080

Cerami, A., \& Vanhuysse, P.(Eds.). (2009). Post-communist welfare pathways: Theorizing social policy transformations in Central and Eastern Europe. Basingstoke: Palgrave.

Churchill, H. (2013). Retrenchment and restructuring: Family support and children's services reform under the coalition. Journal of Children's Services, 8(3), 209-222. https://doi.org/10.1108/ JCS-05-2013-0020

Dearing, H. (2016). Gender equality in the division of work: How to assess European leave policies regarding their compliance with an ideal leave model. Journal of European Social Policy, 26(3), 234-247. https://doi. org/10.1177/0958928716642951

Der Standard. (9 August 2008). SPÖ will kostenloses vorschulisches Bildungsjahr.

Dobrotić, I., \& Blum, S. (2019). Inclusiveness of parental leave benefits in twenty-one European countries: Measuring social and gender inequalities in leave eligibility. Social Politics, 27(3), 588614. https://doi.org/10.1093/sp/jxz023

Esping-Andersen, G. (1990). The three worlds of welfare capitalism. Princeton, NY: Princeton University Press.

Esping-Andersen, G. (1999). Social foundations of postindustrial economies. Oxford: Oxford University Press.

Esping-Andersen, G., Gallie, D., Hemerijck, A., \& Myles, J. (2002). Why we need a new welfare state. Oxford: Oxford University Press.

European Commission. (2013a). Social investment: Commission urges Member States to focus on growth and social cohesion. Brussels: European Commission.

European Commission. (2013b). Towards social investment for growth and cohesion - including implementing the European Social Fund 20142020. COM/2013/083 final.

Eurostat. (2017). Social Protection Statistics. Available at http://ec.europa.eu/eurostat/data/database

Farnsworth, K., \& Irving, Z. (2012). Varieties of crisis, varieties of austerity: Social policy in challenging times. Journal of Poverty and Social Justice, 20(2), 135-149. https://doi. org/10.1332/175982712X652041 
Ferrara, M. (1996). The Southern model of welfare in social Europe. Journal of European Social Policy, 6(1), 17-37. https://doi. org/10.1177/095892879600600102

Filipovič Hrast, M., \& Kopač Mrak, A. (2016). Slovenia: Continuous gradual change of the welfare state. In K. Schubert, P. de Villota \& J. Kuhlmann (Eds.), Challenges to European Welfare Systems (pp. 693-718). New York: Springer.

Filipovič Hrast, M., \& Rakar, T. (2020). Restructuring the Slovenian welfare system: Between economic pressures and future challenges. In S. Blum, J. Kuhlmann \& K. Schubert (Eds.), Routledge Handbook of European Welfare Systems (pp. 483-501). London: Routledge.

Finnish Parliament. (2013). Legislation bill, HE 129/2013 vp. Helsinki: The Finnish Parliament.

Gauthier, A. H. (2010). The impact of the economic crisis on family policies in the European Union. Brussels: European Commission.

Hemerijck, A. (2015). The quiet paradigm revolution of social investment. Social Politics, 22(2), 242256. https://doi.org/10.1093/sp/jxv009

Hemerijck, A. (2017). The uses of affordable social investment. In A. Hemerijck (Ed.), The Uses of Social Investment (pp. 379-412). Oxford: Oxford University Press.

Hood, C., Heald, D., \& Himaz, R. (2014). When the party's over: The politics of fiscal squeeze in perspective. Oxford: Oxford University Press.

Javornik, J. (2014). Measuring state de-familialism: Contesting post-socialist exceptionalism. Journal of European Social Policy, 24(3), 240-257. https://doi.org/10.1177/0958928714525815

Jenson, J. (2009). Lost in translation: The social investment perspective and gender equality. Social Politics, 16(4), 446-483. https://doi.org/10.1093/ sp/jxp019

Kanjuo Mrčela, A., \& Černigoj Sadar, N. (2011). Social policies related to parenthood and capabilities of Slovenian parents. Social Politics, 18(2), 199-231. https://doi.org/10.1093/sp/jxr010

Lammi-Taskula, J., \& Karvonen, S. (Eds.). (2014). Lapsiperheiden hyvinvointi. Helsinki: Terveyden ja hyvinvoinnin laitos.

Leitner, S. (2003). Varieties of familialism: The caring function of the family in comparative perspective. European Societies, 5(4), 353-375. https://doi.org/10.1080/1461669032000127642

Léon, M., \& Pavolini, E. (2014). 'Social investment' or back to 'familism': The impact of the economic crisis on family and care policies in Italy and Spain. South European Society and Politics,
19(3), 353-369. https://doi.org/10.1080/13608746 .2014 .948603

Ministrstvo za delo, družino, socialne zadeve in enake možnosti. (2010). Vlada RS sprejela predlog Zakona o uveljavljanju pravic izjavnih sredstev. Novica, 29 April 2010.

Ministry of Social Affairs and Health. (2011). Memorandum of the Working Group on Family Leaves. 27 August 2009. Helsinki: Ministry of Social Affairs and Health.

Morel, N., Palier, B., \& Palme, J. (2012). Beyond the welfare state as we knew it?. In N. Morel, B. Palier \& J. Palme (Eds.), Towards a social investment welfare state? Ideas, policies and challenges (pp. 1-29). Bristol: The Policy Press.

Morgan, K. (2012). Promoting social-investment through work-family policies: Which nations do it and why?. In N. Morel, B. Palier \& J. Palme (Eds.), Towards a social investment welfare state? Ideas, policies and challenges (pp. 153180). Bristol: The Policy Press.

Nolan, B. (2013). What use is 'social investment'? Journal of European Social Policy, 23(5), 459468. https://doi.org/10.1177/0958928713499177

Nyby, J., Nygård, M., \& Blum, S. (2018). Radical reform or piecemeal adjustments? The case of Finnish family policy reforms. European Policy Analysis, 4(2), 190-213. https://doi.org/10.1002/ epa2.1045

Nyby, J., Nygard, M., Autto, J., Kuisma, M., \& Blum, S. (2017). The role of discourse in family policy reform: The case of Finland. Critical Social Policy, 38(3), 567-588. https://doi. org/10.1177/0261018317745609

Nygård, M., \& Autto, J. (2014). Finnish family policy at the crossroads? The financial crisis and its repercussions on state support for families with children. Paper presented at the Conference of Comparative European Politics, Gothenburg, November 6-7.

Organisation for Economic Co-operation and Development. (2014). Society at a Glance 2014. OECD Social Indicators. Paris: OECD.

Österle, A., \& Heitzmann, K. (2020). Austrification in welfare system change? An analysis of welfare system developments in Austria between 1998 and 2018. In S. Blum, J. Kuhlmann \& K. Schubert (Eds.), Routledge Handbook of European Welfare Systems (pp. 21-37). London: Routledge.

Richardson, D. (2010). Child and family policies in a time of economic crisis. Children \& Society, 24(6), 495-508. https://doi.org/10.1111/j.10990860.2010.00334.x 
Ronchi, S. (2018). Which roads (if any) to social investment? The recalibration of EU Welfare States at the crisis crossroads (2000-2014). Journal of Social Policy, 47(3), 459-478. https://doi. org/10.1017/S0047279417000782

Statistik Austria. (2008, 2015). Kindertagesheimstatistik. Vienna: Statistik Austria.

Stewart, K. (2013). Labour's record on the under fives: Policy, spending and outcomes 1997-2010. Social Policy in a Cold Climate Working Paper 4. London: London School of Economics.

Szelewa, D., \& Polakowski, M.P. (2008). Who cares? Changing patterns of childcare in Central and Eastern Europe. Journal of European Social Policy, 18(2), 115-131. https://doi. org/10.1177/0958928707087589

Van Kersbergen, K., Vis, B., \& Hemerijck, A. (2014). The great recession and welfare state reform: Is retrenchment really the only game left in town?. Social Policy \& Administration, 48(7), 883-904. https://doi.org/10.1111/spol.12063

Wall, K. (2011). A intervenção do Estado: políticas públicas de família. In A. N. Almeida (Ed.) História da vida privada em Portugal: os nossos días. Lisboa: Círculo de Leitores.

Wall, K., Samitca, S., \& Correia, S. (2013). Negotiating work and care in a changing welfare regime. The case of Portugal. In B. Le Bihan, C. Martin \& T. Knijn (Eds.), Work and Care under Pressure. Care Arrangements across Europe. Amsterdam: Amsterdam University Press.

Windebank, J. (2017). Change in work-family reconciliation policy in France and the UK since 2008: The influence of economic crisis and austerity. Journal of International and Comparative Social Policy, 33(1), 55-72. https://doi.org/10.1080 /21699763.2017.1288160

\section{ANNEX}

Table 1

Overview of policy directions 2008-2015

\begin{tabular}{lcccc}
\hline & AT & FI & PT & SI \\
\hline Social-investment policies & Expansion & $\begin{array}{c}\text { Stability, then } \\
\text { reduction }\end{array}$ & Stability & $\begin{array}{c}\text { Stability + } \\
\text { slight reduction }\end{array}$ \\
\hline $\begin{array}{l}\text { Childcare (quantity, access, } \\
\text { affordability) }\end{array}$ & Stability & $\begin{array}{c}\text { Stability, then } \\
\text { expansion }\end{array}$ & Reduction & Stability \\
\hline Childcare (quality) & Expansion & Expansion & $\begin{array}{c}\text { Slight } \\
\text { Expansion }\end{array}$ & Expansion \\
\hline $\begin{array}{l}\text { Gender-equal leave } \\
\text { regulations }\end{array}$ & $\begin{array}{c}\text { Expansion }+ \\
\text { Social-protection policies }\end{array}$ & $\begin{array}{c}\text { Expansion, } \\
\text { then reduction }\end{array}$ & $\begin{array}{c}\text { Reduction } \\
\text { (lately slight } \\
\text { expansion) }\end{array}$ & Reduction \\
\hline Family cash/tax benefits & Stability & Stability & Stability & Stability \\
\hline Familialist leave regulations & Stuction &
\end{tabular}

Categories: Expansion of benefits/services; reduction of benefits/services; stability of benefits/services. Source: Own case studies; see Table 1 in Bothfeld, \& Rouault, 2013. 
Sažetak

\title{
SOCIJALNO ULAGANJE U DOBA ŠTEDNJE: USPOREDBA REFORMI OBITELJSKE POLITIKE U ČETIRI EUROPSKE ZEMLJE
}

\author{
Sonja Blum \\ FernUniversität in Hagen \\ Hagen, Germany \\ Sónia Correia \\ Institute of Social Sciences \\ University of Lisbon \\ Lisbon, Portugal \\ Mikael NygÅrd \\ Faculty of Education and Welfare Studies \\ Åbo Akademi University \\ Vaasa, Finland \\ Tatjana Rakar \\ Faculty of Social Sciences \\ University of Ljubljana \\ Ljubljana, Slovenia \\ Karin Wall \\ Institute of Social Sciences \\ University of Lisbon \\ Lisbon, Portugal
}

Ovaj je rad usmjeren na reforme obiteljske politike u četiri europske zemlje - Austriji, Finskoj, Portugalu i Sloveniji-između 2008. i 2015. godine. Te su godine obilježile „velika recesija" $i$ uspon perspektive socijalnog ulaganja. Međutim, socijalno ulaganje je opći pojam i pomalo je dvosmislen. Ovaj rad razlučuje između različitih varijanti socijalnog ulaganja koje proizlaze iz usredotočenosti na interakcije socijalnog ulaganja i alternativnih perspektiva socijalne politike, $i$ to socijalne zaštite $i$ štednje. U radu se identificiraju različite varijante u smislu stupnja socijalnog ulaganja: od sveobuhvatnog, preko istiskivanja do „skromnijih“ oblika socijalnog ulaganja. To je dovelo do oštrih rezova u obiteljskim novčanim davanjima, dok su se područja javne skrbi i roditeljskog dopusta pokazala otpornijima u analiziranim zemljama. Ovi su zaključci indikativni u sadašnjoj pandemiji COVID-19, kada se zemlje suočavaju s novom, možda i većom gospodarskom krizom.

Ključne riječi: obiteljska politika, kriza, socijalno ulaganje, štednja, studije slučaja. 